\title{
ISOLASI ENZIM SELULASE DARI PANKREAS KEONG MAS
}

\author{
Sri Hilma Siregar \\ Jurusan Kimia, Fakultas MIPA dan Ilmu Kesehatan \\ Universitas Muhammadiyah Riau \\ Email: srihilma_siregar@yahoo.com
}

\begin{abstract}
Extract the cellulose was prepared by the precipitation method using aceton $50 \%(\mathrm{v} / \mathrm{v})$ and its protein content was analized by Biuret method. The sugar content as the result of the hydrolization of cellulose was determined by Nelson Somogyi method. After precipitation of the protein enzyme, centrifugation and freeze drying were applied and the specific activity of he enzyme cellulose extract was $0.1012 \mathrm{U} / \mathrm{mg}$ protein in optimal condition of $\mathrm{pH} 4.5$ and temperature $45^{\circ} \mathrm{C}$, where as the maximum velocity $32.94 \mu \mathrm{g} / \mathrm{ml} / \mathrm{min}$ and $\mathrm{K}_{\mathrm{M}}$ value were 0.7279 $\mathrm{mg} / \mathrm{ml}$. Respectively the purification fold was 3.58 times and the $\%$ recovery was $52.95 \%$.
\end{abstract}

Key words : Gold Snail, Cellulose

\section{PENDAHULUAN}

Keong mas atau siput murbei adalah keong air tawar yang berasal dari Amerika Utara dan Amerika Selatan. Pada tahun 1983, siput ini mulai diperkenalkan di Filipina dengan tujuan untuk menigkatkan produksi pangan, diversifikasi sumber protein, dan sebagai komoditas ekspor.

Modus kehadiran keong mas di Indonesia berbeda dengan di Filipina. Pada awalnya ada diantara penggemar ikan hias yang mengoleksi dan memelihara dengan kepedulian terhadap hewan tersebut. Tingkat kepedulian terhadap keong mas tersebut semakin lama semakin berkurang dan akhirnya terlepas dari upaya budidaya yang terkendali, menyebar di perairan bebas. Keong mas merupakan musuh utama bagi para petani di Indonesia saat ini karena keganasannya merusak tanaman padi di areal persawahan. Keong mas merupakan hewan herbivora yang sangat rakus makan padi muda.

Sewaktu keong mas ditangkap dari sawah, biasanya sebagai sisa makanan masih tertinggal didalam perut keong mas. Sisa makanan tersebut kurang menguntungkan apabila keong mas diolah untuk dikonsumsi, sehingga perut keong mas dibuang agar tidak ikut dimasak. Padahal dalam getah lambung dan pankreas terdapat enzim yang bermanfaat bagi industri pangan yaitu enzim yang dapat menghidrolisa selulosa menjadi glukosa, sedangkan glukosa merupakan sumber energi bagi hewan tersebut. Isolasi enzim selulase bertujuan untuk mendapatkan enzim selulase yang dapat digunakan untuk mengkonversi selulosa menjadi glukosa dalam industri pangan (11).

$$
\text { Melihat kondisi ini maka }
$$
dilakukanlah berbagai uapaya untuk mengatasinya sekaligus mencari alternative pemanfaatan keong mas sehingga penulis sangat tertarik untuk meneliti enzim selulase dari pankreas keong mas sehingga diharapkan keong mas dapat bermanfaat bagi kehidupan manusia dan juga dapat mengatasi masalah pencemaran yang disebabkan oleh keong mas. 


\section{METODOLOGI PENELITIAN}

Bahan yang dipergunakan dalam penelitian ini adalah Pankreas Keong Mas dan glukosa anhidrat. Alat yang dipergunakan adalah Sentrifuse, Spektrofotometer spektronik 2D dan incubator.

Ekstrak selulase diperoleh dengan metode pengendapan menggunakan aseton dengan konsentrasi $50 \% \quad(\mathrm{v} / \mathrm{v})$ dan kandungan proteinnya dianalisa dengan metode Biuret. Pengukuran kadar gula reduksi hasil hidrolisas selulase ditentukan dengan metode Nelson Somogyi.

\section{HASIL DAN PEMBAHASAN}

Data Kadar Protein Ekstrak

Untuk mengetahui kadar protein yang teerkandung dalam ekstrak pankreas keong mas dilakukan analisa menurut metode Biuret. Dalam hal ini dipakai standar protein dari bovin serum albumin dengan hasil serapan ditunjukkan dalam Tabel 1.

Tabel 1. Data resapan larutan Bovin Serum Albumin standar dalam berbagai konsentrasi pada kondisi optimum

\begin{tabular}{|c|c|c|c|c|}
\hline No & $\begin{array}{c}\text { Konsentrasi } \\
(\mathrm{mg} / \mathrm{ml})(\mathrm{X})\end{array}$ & $\begin{array}{c}\text { Absorbansi } \\
(\mathrm{Y})\end{array}$ & $\mathrm{X}^{2}$ & $\mathrm{X} . \mathrm{Y}$ \\
\hline 1 & 1,0 & 0,114 & 1,0 & 0,114 \\
2 & 1,5 & 0,131 & 2,25 & 0,197 \\
3 & 2,0 & 0,149 & 4,0 & 0,298 \\
4 & 2,5 & 0,168 & 6,25 & 0,420 \\
5 & 3,0 & 0,187 & 9,0 & 0,561 \\
6 & 3,5 & 0,208 & 12,5 & 0,728 \\
7 & 4,0 & 0,237 & 16,0 & 0,948 \\
8 & 4,5 & 0,268 & 20,25 & 1,206 \\
9 & 5,0 & 0,292 & 25,00 & 1,46 \\
\hline & $\mathrm{X}=27$ & $\mathrm{Y}=1,754$ & 96,25 & 5,932 \\
\hline
\end{tabular}

Dimana:

$$
\begin{aligned}
& \mathrm{X}=\text { Konsentrasi BSA mg/ml } \\
& \mathrm{Y}=\text { Absorbansi } \\
& b=\frac{n\left(\sum X Y\right)-\left(\sum X\right)\left(\sum Y\right)}{n\left(\sum X^{2}\right)-\left(\sum X\right)^{2}} \\
& b=\frac{y(5,932) \quad(27)(1,754)}{Y(96)-(27)^{2}} \\
& b=0,0446
\end{aligned}
$$

$$
\begin{aligned}
& u=\frac{\sum X^{2} Y-\sum X \sum X Y}{n \sum X^{2}-\left(\sum X\right)^{2}} \\
& u=\frac{96(1,754)-27(5,932)}{y(96)-(27)^{2}}
\end{aligned}
$$

Sehingga diperoleh persamaan garis regresinya adalah $\mathrm{Y}=0,0611+0,0446 \mathrm{X}$

Sehingga dari persamaan regresi kita dapat menghitung kadar protein dari ekstrak kasar enzim selulase.

1. Kadar protein ekstrak pankreas keong mas sebelum isolasi $2,71 \mathrm{mg} / \mathrm{ml}$

2. Kadar protein ekstrak kasar enzim sesudah isolasi dengan aseton $1,19 \mathrm{mg}$ $/ \mathrm{ml}$

\section{Perhitungan Aktivitas Ekstrak Enzim Selulase}

Satuan aktivitas suatu enzim dinyatakan dengan unit aktivitas. Sedangkan yang dimaksud dengan satu unit aktivitas ekstrak addalah banyaknya $\mu$ mol glukosa yang dihasilkan per $\mathrm{ml}$ ekstrak enzim per menit dalam kondisi optimum, dimana 1 unit $=1$ $\mu \mathrm{mol} / \mathrm{ml} / \mathrm{menit}$.

Aktivitas ekstrak enzim $=\mu \mathrm{mol} /$ menit

$$
\begin{aligned}
& =6,078 / 60 \text { menit } \\
& =0,1013 \mathrm{U}
\end{aligned}
$$

Aktivitas spesifik

$$
\begin{aligned}
& =0,1013 \mathrm{U} / 1,203 \mathrm{mg} \text { protein } \\
& =0,0842 \mathrm{U} / \mathrm{mg} \text { protein }
\end{aligned}
$$

\section{Penentuan Laju Reaksi dan Nilai $K_{M}$ Ekstrak Kasar Enzim selulase dalam Substrat Selulosa}

Nilai KM ekstrak kasar enzim selulase diperoleh apabila telah diketahui laju reaksi maksimum. Laju reaksi dari hidrolisa substrat selulosa oleh ekstrak ditentukan dengan cara konsentrasi substrat divariasikan sedangkan lama inkubasi dibuat tetap 60 menit, $\mathrm{pH}$ optimum 4,5, suhu optimum $45^{\circ} \mathrm{C}$. Setelah diperoleh data 
resapan disubstitusikan ke persamaan regresi glukosa standar .Haslnya dibagi lama inkubasi maka diperoleh laju reaksi.

Untuk mendapatkan laju reaksi maksimum adalah dengan memplotkan datadata $1 /[\mathrm{S}]$ sebagai absis dan data I/V sebagai ordinat. Data lengkapnya ditunjukkan dalam table di bawah ini.

Tabel 2. Data Resapan dan Laju Aktivitas Ekstrak Enzim Selulase dalam Substrat Selulosa pada kondisi optimum

\begin{tabular}{|c|c|c|c|c|c|c|c|}
\hline $\mathrm{NO}$ & $\begin{array}{c}{[\mathrm{S}]} \\
\mathrm{mg} / \mathrm{ml}\end{array}$ & $\begin{array}{c}1 /[\mathrm{S}] \\
(\mathrm{X})\end{array}$ & $\mathrm{A}$ & $\begin{array}{c}{[\text { Glukosa }]} \\
\mathrm{mg} / \mathrm{ml}\end{array}$ & $\mathrm{V}$ & $1 / \mathrm{V}$ & $1 / \mathrm{V} .1 / \mathrm{S}$ \\
\hline 1 & 0,5 & 2,0 & 0,450 & 0,793 & $1,33.10^{-2}$ & 75 & 150 \\
2 & 1 & 1,0 & 0,536 & 1,093 & $1,82.10^{-2}$ & 54,95 & 54,95 \\
3 & 2 & 0,5 & 0,810 & 1,532 & $2,5.10^{-2}$ & 40 & 20 \\
4 & 3 & 0,33 & 0,844 & 1,602 & $2,676.10^{-2}$ & 37,5 & 12,38 \\
5 & 4 & 0,25 & 0,877 & 1,668 & $2,78.10^{-2}$ & 36,0 & 9 \\
6 & 5 & 0,20 & 0,888 & 1,692 & $2,82.10^{-2}$ & 35,5 & 7,1 \\
\hline & & $\mathrm{X}=4,28$ & & & 278,95 & 253,43 \\
\hline
\end{tabular}

$b=\frac{n\left(\sum X Y\right)-\left(\sum X\right)\left(\sum Y\right)}{n\left(\sum X^{2}\right)-\left(\sum X\right)^{2}}$

$\mathrm{b}=22,61$

$u=\frac{\sum X^{2} \sum Y-\sum X \sum X Y}{n\left(\sum X^{2}\right)-\left(\sum X\right)^{2}}$

$\mathrm{a}=30,36$

Sehingga :

$\mathrm{V}_{\text {maks }}=1 / \mathrm{a}=1 / 30,36=0,03294 \mathrm{mg} / \mathrm{ml} / \mathrm{min}$

$$
=32,94 \mu \mathrm{g} / \mathrm{ml} / \mathrm{min}
$$

Gradien (b) $=\mathrm{K}_{\mathrm{M}} / \mathrm{V}_{\text {maks }}$

$$
\begin{aligned}
\mathrm{K}_{\mathrm{M}} & =\mathrm{V}_{\text {maks }} \times \mathrm{b} \\
& =0,03294 \times 22,61 \\
& =0,7279 \mathrm{mg} / \mathrm{ml} \\
\mathrm{K}_{\mathrm{M}} & =4,04 \cdot 10^{-3} \mathrm{M}
\end{aligned}
$$

Perhitungan Tingkat Kemurnian Ekstrak

\section{Kasar Enzim Selulase}

Guna mengetahui tingkat kemurnian enzim perlu diketahui jumlah volume larutan protein, kandungan protein, kandungan total protein, aktivitas enzim, aktivitas total enzim, dan aktivitas spesifik enzim. Aktivitas total adalah aktivitas ekstrak enzim persatuan volume dikali dengan volume total larutan protein.

a. Sebelum isolasi dengan penambahan aseton

Kadar protein $=2,713 \mathrm{mg} / \mathrm{ml}$

Volume total larutan protein sebelum isolasi $=300 \mathrm{ml}$

Dan aktivitasnya $=0,17721 \mathrm{U} / \mathrm{ml}$

Total unit $=0,17721 \mathrm{U} / \mathrm{ml} \times 300 \mathrm{ml}$

$$
=53,163 \text { Unit }(\mathrm{U})
$$

Aktivitas spesifik $=0,17721 \mathrm{U} / \mathrm{ml} /$ $2,713 \mathrm{mg}$ protein $/ \mathrm{ml}=6,53 \cdot 10^{-2} \mathrm{U} / \mathrm{mg}$ protein

b. Sesudah isolasi dengan penambahan aseton $50 \%$

Kadar protein $\quad=1,203 \mathrm{mg} / \mathrm{ml}$

Volume larutan total $=100 \mathrm{ml}$

Aktivitasnya $\quad=0,2815 \mathrm{U} / \mathrm{ml}$

Total unit $=0,2815 \mathrm{U} / \mathrm{ml} \mathrm{x} 100 \mathrm{ml}$

$$
=28,15 \mathrm{U}
$$

Aktifitas spesifik:

$=0,2815 \mathrm{U} / \mathrm{ml} / 1,203 \mathrm{mg}$ protein $/ \mathrm{ml}$ $=2,34 \cdot 10^{-1} \mathrm{U} / \mathrm{mg}$ protein 
Aktivitas spesifik adalah aktivitas total ekstrak enzim dibagi dengan kandungan total protein.

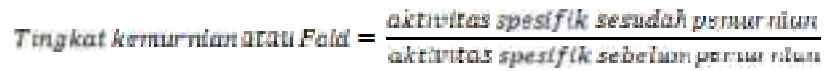

$=\frac{2,34 \cdot 10^{-1} U / m g p r o t e t h}{6,33 \cdot 10^{-2} U / m g p r o t e i n}$

$=3,58 \mathrm{kali}$

Kecovery $[\%]=\frac{\text { Total unit sesudah perrar nian }}{\text { Total unit sebelum pemarnian }} \times 200 \%$

$=\frac{28,12 \mathrm{U} / \mathrm{mgprotein}}{53,103 \mathrm{U} / \mathrm{mgprotein}} \times 100 \%$

$=52,95 \%$

Dari hasil penelitian terjadi peningkatan aktivitas pada ekstrak kasar enzim selulase hasil pengendapan dengan aseton dibandingkan dengan aktivitas ekstrak enzim sebelum diisolasi. Hal ini disebabkan semakin berkurangnya kadar protein yang terkandung dalam ekstrak enzim yang diperoleh semakin murni. Tingkat kemurnian (fold) adalah perbandingan aktivitas spesifik total ekstrak enzim sesudah pemurnian terhadap aktivitas spesifik total sebelum pemurnian. Dari penelitian ini diperoleh 3,58 kali, ini berarti menunjukkan aktivitas spesifik total ekstrak enzim melalui tahap pengendapan dengan aseton mengalami peningkatan kemurnian sebesar 3,58 kali dibandingkan dengan ekstrak kasar enzim sebelum isolasi dan recovery yang didapatkan 52,95\%. Ini menunjukkan bahwa tingkat kemurnian belum sesuai dengan apa yang diharapkan yaitu mendekati $100 \%$. Dengan tingginya nilai recovery menunjukkan tingginya tingkat kemurnian enzim selulase.

\section{KESIMPULAN}

Dari seluruh hasil penelitian yang telah dilakukan maka dapat diambil kesimpulan mengenai ekstrak kasar enzim selulase dari ekstrak pankreas keong mas yang menghidrolisis substrat selulosa adalah: Aktivitas spesifik ekstrak kasar enzim selulase hasil isolasi parsial optimum adalah $0,0841 \mathrm{U} / \mathrm{mg}$ protein, sedangkan aktivitas enzim selulase pada kondisi optimum 0,1012 U. Laju reaksi maksimum ekstrak kasar enzim selulase dalam substrat selulosa adalah 32,94 $\mu \mathrm{g} / \mathrm{ml} / \mathrm{min}$ sedangkan nilai KM yang diperoleh adalah 0,7279 $\mathrm{mg} / \mathrm{ml}$ atau 4,04.10-3 M. tingkat kemurnian (fold) ekstrak kasar enzim selulase adalah 3,58 kali dan recovery sebesar 52,95\%.

\section{DAFTAR PUSTAKA}

AOAC.," "Official Methods of Analysis," 1984., 397-398

Athel Cornish-Bowden, "Fundamentals of Enzyme Kinetics", Butterworth dan Co. (Publishers)ltd, London, 1979.

Cole,F.E., and King, K.W., "Site of Hydrolisis of Cellulodextrins and Reduced Celludextrins by purified Cellulase Components", Biochemistry, Biophys.Acta, 1964.81:122-129

Fengel, D. dan Weneger, G., "Kayu Kimia: Ultrastruktur, Reaksi-reaksi”, Gajah Mada Universitas Press, Yogyakarta, 1995, hal 437-447.

Girindra, A., "Biokimia I", PT. Gramedia Pustaka Umum, Jakarta, 1993, hal 3391.

Holme, D.J., Peck, H., "Analytical Chemistry”, Longman, London, 1983, hal 33-91

Houston, "Rice Chemistry and Technology", American Association of Cereal Cememist Inc., USA., 1972, page 309 
Pathak, A.N., and Ghose, T.K., "Cellulases1:Sources, Technology”, Proses Biochemistry 1973, 8(4):35

Pathak, A.N., and Ghose, T.K., "Cellulases2:Sources, Technology”, Proses Biochemistry 1973, 8(5):20

Ritzman, M., "Metodologi Isolasi Enzim dan Aktivitasnya", PAU ITB, Bandung, 1991.

Schimer Sigmund, "Source Book of Food Enzymology", The AVI Publishing Company Inc., Connecticut, USA, 1981.

Setijo Pitojo, "Petunjuk Pengendalian dan Pemanfaatan Keong Mas", Trubus Agriwidya, Ungaran, 1996, hal 12-15.

Shahib, M.N., "Pemahaman Seluk Beluk Biokimia dan Penerapa Enzim”, PT. Citra Aditya Bakti, Bandung, 1992, hal $1-10$.
Sudarmaji, S., "Prosedur Analisa Untuk Bahan Makanan dan Pertanian", Edisi ke-13, Liberty, Yogyakarta, 1984, hal 32-33.

Sudjana, "Desain dan Analisa Eksperimen", Penerbit Tarsito, Bandung, 1994.

Susanto, H., "Siput Murbei Pengendalian dan Pemanfaatannya”, Kanisius, Yogyakarta, 1995.

Tracy I. Storer, "Elements of Zoology", Mc.Graw-Hill Book Company, Inc., California, 1961.

Winarno, F.G., "Enzim Pangan”, Erlangga, Jakarta, 1995, hal 38-39; 62-63.

Wirahadikusuma, M., "Biokimia: Protein, Enzim, dan Asam Nukleat", ITB, Bandung, 1981, hal 6-9;40-45. 